\title{
(C) OPEN ACCESS \\ Pharmaceuticals and modern statecraft in South Africa: the cases of opium, thalidomide and contraception.
}

\author{
Julie Parle, ${ }^{1}$ Rebecca Hodes, ${ }^{2}$ Thembisa Waetjen ${ }^{3}$
}

\begin{abstract}
'School of Social Sciences, University of KwaZulu-Natal, Pietermaritzburg, KwaZuluNatal, South Africa

${ }^{2}$ AIDS and Society Research Unit, Centre for Social Science Research, Institute for the Humanities in Africa, University of Cape Town, Cape Town,

South Africa

${ }^{3}$ History, University of

Johannesburg, Auckland Park, South Africa
\end{abstract}

\section{Correspondence to}

Professor Julie Parle, History, School of Social Science, University of KwaZulu-Natal, Pietermaritzburg 3201, South Africa; parlej@ukzn.ac.za

JP, RH and TW contributed equally.

Accepted 24 September 2018

Check for updates

(C) Author(s) (or their employer(s)) 2018. Re-use permitted under CC BY-NC. No commercial re-use. See rights and permissions. Published by BMJ.

To cite: Parle J, Hodes R Waetjen T. Med Humanit 2018:44:253-262.

\section{ABSTRACT}

This article provides a history of three pharmaceuticals in the making of modern South Africa. Borrowing and adapting Arthur Daemmrich's term 'pharmacopolitics', we examine how forms of pharmaceutical governance became integral to the creation and institutional practices of this state. Through case studies of three medicaments: opium (late 19th to early 20th century), thalidomide (late 1950s to early 1960s) and contraception (1970s to 2010s), we explore the intertwining of pharmaceutical regulation, provision and consumption. Our focus is on the modernist imperative towards the rationalisation of pharmaceutical oversight, as an extension of the state's bureaucratic and ideological objectives, and, importantly, as its obligation. We also explore adaptive and illicit uses of medicines, both by purveyors of pharmaceuticals, and among consumers. The historical sweep of our study allows for an analysis of continuities and changes in pharmaceutical governance. The focus on South Africa highlights how the concept of pharmacopolitics can usefully be extended to transnational-as well as local - medical histories. Through the diversity of our sources, and the breadth of their chronology, we aim to historicise modern pharmaceutical practices in South Africa, from the late colonial era to the Post-Apartheid present.

\section{INTRODUCTION: PHARMACEUTICALS AND MODERN STATECRAFT IN SOUTH AFRICA}

The field of medical humanities invites scholars to be adventurous. ${ }^{1}$ It encourages interdisciplinary methods and new lines of critical enquiry in exploring the vast, heterogeneous domains of human health and illness. It is in this spirit of intellectual risk-taking that this article combines historical case studies of three very different medicaments with a political analysis of their role in the emergence and constitution of the modern state in South Africa. Its chronological sweep is broad, beginning in the late 19th century and ending roughly in the present. It is through the long duration of this study that its key insights emerge, and that both contingencies and continuities in pharmaceutical governance come into view. Our principal focus is on a single nation, South Africa, and we draw extensively on primary archival material including documents and photographs, parliamentary debates, the meeting minutes of professional medical bodies and oral interviews. Where available, secondary sources helped to trace the uses, regulations and adaptations of the medicaments at our study's centre. But in conceptualising their interrelationship, that is, the connections between medicaments and modern statecraft, we have drawn from a wider and more eclectic literature. Our sources encompass the history and sociology of science and of the state in South Africa, ${ }^{23}$ as well as studies of pharmaceutical governance, or 'pharmacopolitics, ${ }^{4}$ and of medicines and modernity. ${ }^{5}$

'Modernity', as a unitary concept, remains much disputed. Useful are Weberian interpretations of modernity as defined by a constellation of social processes, including the growth, differentiation and integration of bureaucracy, and its extension, through various political mechanisms, into arenas of social existence. We focus on facets of this process as they relate to the creation and consolidation of South Africa's modern pharmacopolitics to illustrate that modernity's components are discernible transcontinentally. At modernity's epistemological base is a system of calculative and evaluative thought which drove mercantilist and administrative governments in Western Europe from the early modern period. ${ }^{6}$ Broadly sketched, we show that the South African experience of these processes and practices illustrates the uneven, discriminatory and contested integration of African colonial spaces and societies into global economic and political institutions, even as the political formations of empire were giving way to those of nation. During the era of the new imperialism of the late 19th and 20th centuries, these designs were applied in the formation of colonial regimes in Africa. The brutality of this process, and its consequences for the health of local populations, is the subject of much postcolonial scholarship. ${ }^{7-14}$

In her study of modernity in Apartheid South Africa, Deborah Posel states that the concept of 'the modern' is, in part, an avowal of historical interconnectedness. She also asserts the importance of contextual and historical specificity in analysing its local instantiations. For Posel, it was the 'modernist confidence in the powers of the central state as an agent of large-scale social transformation', in combination with an ideology of white supremacy, and a commitment to white economic prosperity, that are the key features of modern South African statecraft over the long 20th century. ${ }^{15}$ Posel's characterisation of these three features is relevant in conceptualising medical modernity in South Africa which saw the (often erratic and limited) expansion of bureaucratic and regulatory powers 
in pharmaceutical governance, and the entanglement of local actors and agents, powerful state investment in the ideologies of race and the workings of the market economy, which are best understood as being shaped by global as well as local forces.

Our findings are based on three ongoing research projects concerned with three very different pharmaceutical products, each of which was influential at a particular time in the development of pharmacological modernity in South Africa. Although not comparable in terms of chemical composition, uses, effects or cultural meanings, it is their shared nature as mobile medical commodities, with properties potentially both therapeutic and risky, that distinguished them among other available substances and products in their respective historical 'moments', making them pertinent choices.

The first example traces early 20th century politics of opium to demonstrate the shifting meanings of an imported drug, and its role in producing relations of regulatory power and biochemical governance. It shows how the politics of race mediated contradictions of early capitalist settler colonialism, offering differential provision-to 'civic' and 'labouring' bodies—rooted in categories of colonial subjecthood. The second example develops the theme of regulation further. It focuses on the fetal deformity-causing drug thalidomide. Because of the interplay of international and local pharmacopolitics, thalidomide had little or no actual direct impact on individuals on the African continent in terms of its disastrous teratogenic side-effects. Importantly, however, the inescapable conclusion that modern drugs could be highly damaging helped to create a political climate that pushed forward the reconfiguration of the South African medicines regulatory regime. The final example describes the entanglements of the politics of race and gender within contemporary histories of contraception. The establishment of a massive, statewide contraception programme was a means by which the Apartheid state sought to curb demographic growth among the black population. Yet, this programme cannot be understood merely as an imposition by white state authorities onto black patients. Rather, Apartheid family planning is better understood as autocratic in origin, but popular in practice among many patientsfor whom it provisioned greater reproductive freedom. Spanning both the Apartheid and post-Apartheid decades, this section explores continuities and changes in the provision and use of reproductive technologies over the last five decades. It moves from descriptions of state regulation and control to explore patient agency-adding another central component of modern South African medical politics.

\section{THREE CASE STUDIES IN THE HISTORY OF SOUTH AFRICA'S PHARMACOPOLITICS Opium provision and state control in the early 20th century: the making of South African 'pharmacopolitics'}

The making of South African pharmacopolitics was, in important ways, the legal project of colonial state builders, who institutionalised racial and cultural distinctions between human bodies and prescribed their differential biochemical governance. This began with narcotics regulation, during the first decade of the 20th century. The focus was on an imported drug, opium, a product of the poppy plant (Papaver somniferum), whose alkaloids-mainly morphine-were introduced into many overthe-counter patent medicines during the 19th century. ${ }^{16-18}$ As elsewhere, this politics produced and enforced definitions of what constituted, alternately, a medicine and a controlled substance. Through the regulation of opium, in different forms and for different populations, the nascent state produced a set of normative controls and protocols that would shape developments later in the century.

The 19th century brought momentous social, political and economic changes to South Africa. It saw vast movements and migration and, through a brutal process of consolidation which included the South African War (1899-1902), the declaration of Union in 1910. Labour-hungry enterprises in minerals and commercial agriculture brought migration both transcontinentally and from around southern Africa. From 1860, the Natal colonial state transported almost 185000 indentured Indian men and women to work in sugar plantations. Between 1904 and 1910, the imperial government of the Transvaal recruited 63000 men from China for indentured labour in the gold fields. During and after the South African War, thousands of military personnel, entrepreneurs and medical and pharmaceutical professionals migrated from Britain and Europe to southern Africa. These various migratory streams brought new biochemical substances and commodities, as well as new therapeutic and intoxicant practices, to the region at the very moment when imperial and self-ruling states around the world were seeking to regulate the trade and consumption of narcotics, especially opium.

The South African War and its aftermath were significant for the local story of opium regulation in two respects. First, as Africans were drawn into the conflict and as migration routes were restricted, the mining sector faced a shortage of local labour. Second, post-war hostilities between the descendants of Dutch settlers, known as 'Boers', and the victorious 'British', continued to simmer. The new colonial state imposed a comprehensive agenda of progressivist social reform and economic engineering, in service to the economic advancement of white citizenry. Among the controversial innovations championed by imperial administrators was a strategy to save the flagging gold economy by recruiting overseas labour. The indenture of Chinese migrants as unskilled and low-paid miners greatly alienated some factions among the white labouring classes and settler electorate, which contributed to a shift of parliamentary power and the rise of the Boer-led Het Volk Party. These political developments shaped the way opium politics unfolded, as the issue of its control emerged adjacent to distinctive concerns and with different discourses for, on the one hand, labouring Chinese men (confined, exploited and without civic rights) and, on the other, the free white denizens of town and countryside.

From 1904, the arrival of Chinese indentured migrants generated a rush, by variously positioned entrepreneurs, to supply them with opium. The evidence overwhelmingly suggests that, although mine administrators repeatedly claimed that labourers 'brought their habit with them', most who developed a dependency began smoking opium within the closed compound drug economies of the Witwatersrand. ${ }^{19}$

In 1905, the Transvaal government, in consultation with the colony's newly established Medical Council and Pharmacy Board, passed restrictive legislation. The professional bodies inserted a 'medicinal use' clause into the law that allowed doctors, and licensed druggists and chemists to supply opium to individuals with a 'confirmed habit'. ${ }^{20}$ This measure had monumental consequences, allowing for the legal sale of tons of opium by pharmacists. But the local traffic in smuggled opium quickly surpassed authorised quantities and illicit and legitimate circulations became mutually intertwined.

A year later, with rising opium-related casualties and reports of crime, desertion, worker unrest, as well as draconian methods of labour control by mine management, the Chamber of Mines and the Transvaal Pharmacy Board lobbied for reforms. The 

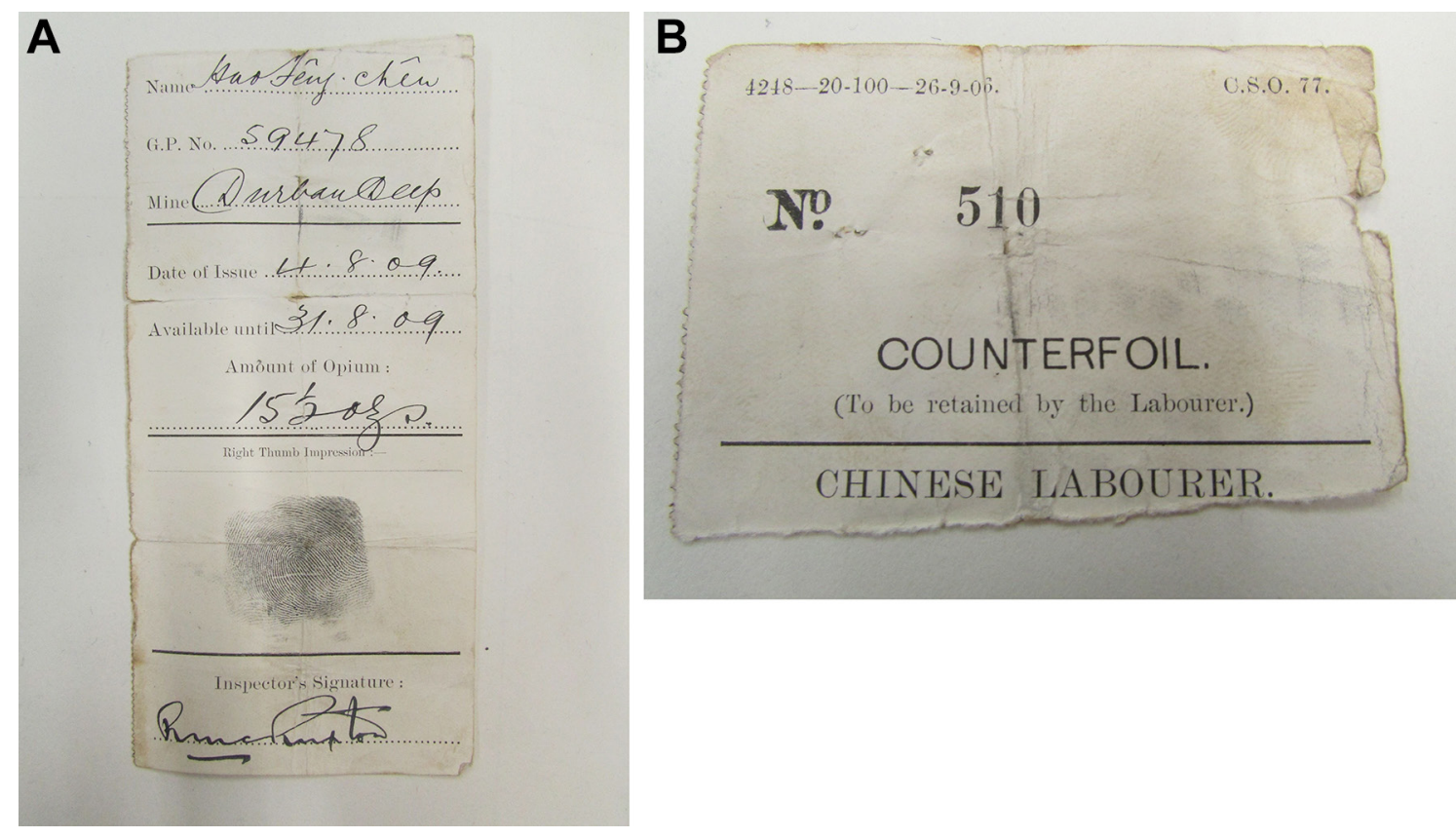

Figure 1 An opium permit (with counterfoil), for Hao Fêng Chên, indenture no 59478, Durban Deep Mine, for 15.5 oz for the month of August 1909. (National Archives, Pretoria. TAB FLD 230 68/52).

state passed a new law to introduce a formal system of opium supply to Chinese mine workers. In effect, opium in its smokable forms was officially reclassified from illicit drug to mine medicine. The new law provided for up to two pounds in weight monthly to individuals on medical prescription (figure 1A,B). During the subsequent 24 months, pharmacists imported eight tons for a physically confined labour force. ${ }^{21}$ They did so within an international climate of rising anti-opium sentiment.

The indenture scheme was officially terminated by the new Het Volk cabinet early in 1907, after which incremental repatriation of Chinese migrants began. By 1909, only the last cohorts remained. In February of that year, representatives of various governments met in Shanghai to establish terms by which the formidable international trade in opium-dominated by British Indian production for the Chinese market-could be curtailed and controlled. In June, to comply with the Shanghai agreements, the Transvaal state recriminalised opium. Jan Smuts, Colonial Secretary in the Het Volk cabinet, presided over this legislation. $\mathrm{He}$ did so against the wishes of the Chamber of Mines, representing the measure as a demonstration of compliance both with international law and with the wishes of the local white electorate, as well as a measure required to intervene in the 'racemixing' which opium dens were rumoured to encourage.

The consultative role of professional pharmacy in these developments bolstered its authority, political power and financial position, as it did organised medicine more generally. A monopoly over legitimate opium sales awarded significant profits to scores of licensed druggists and chemists. State administrators, determined to showcase how modernist principles of scientific management guided colonial governance, were mostly content to rely on the biochemical expertise of medical professionals.

Still, contemporary understandings of opioid addiction were uncertain and contested, often framed racially or ethnographically. Claims about universal physiology were readily supplemented or overwritten by assertions about Chinese bodies or customs. For example, officials with experience of imperial service in Asia sometimes portrayed Chinese people as either especially prone to opiate use or especially resilient to its deleterious effects. ${ }^{19}$ As legislators shifted law from prohibition to provision, they negotiated the ambiguities of scientific evidence and drew on such narratives, in ways that favoured the requirements of gold production. ${ }^{22}$

In the case of Chinese miners, with a few dissenting voices, medical and pharmaceutical lobbies found their expertise, authority and professional interests in direct alignment with the interests of mining capital and the political agendas of the colonial state. Yet, parallel efforts by the Transvaal Pharmacy Board and the Medical Council to exert control over other forms of opium, and for other populations, were notable failures, placing these professional bodies in conspicuous conflict with the government. Their aims to monopolise control and sales over patent medicines-medicinal commodities frequently containing alcohol, opium and other habit-forming substances-emulated the regulatory measures pursued by their political counterparts in other Anglophone societies, most notably Britain, Australia, Canada and the USA. ${ }^{23}$

A wide range of narcotic nostrums were freely available for purchase, including remedies customarily used by British settlers and Boer farming families. From 1904, pharmacists worked to convince the Transvaal government that opium in all its forms constituted an addictive substance that required management by qualified and licensed experts, regulated through law. Yet some lawmakers, happy enough to see legislation in place to control access to opium for 'uncivil' foreign workers, were appalled by the idea that the state should have a hand in regulating opium required by 'ordinary white patients'. ${ }^{22}$

The Transvaal Pharmacy law of 1904 did list opioid medicines as a scheduled 'poison' but mechanisms to enforce controls over prescription and retail practices, especially in the countryside, remained ineffectual. When, in 1905, at the behest of the Pharmacy Board, the state amended the pharmacy law to further limit sales of narcotic medicines by unlicensed parties (such as general dealers, village shopkeepers and farm stores suppliers), protests 
among Dutch-speaking farmers erupted across the region. Cries of 'farmercide' indicated a deep suspicion that the governmental campaign-which essentially deprived Boer farming families of their traditional medicines-constituted a further imperial assault on a population recently decimated by the loss of life in British-created concentration camps during the South African War. ${ }^{17}$

As pressures mounted on these popular fronts, Het Volk party representatives like Smuts warned the Pharmacy Board against pushing for drug control measures that 'could set the whole country aflame, ${ }^{24}$ With the consolidation of four colonies under the Union of South Africa, pharmaceutical lobbies were pushed aside by the emerging state's efforts to solidify nationalism and to advance a common civic identity among people it constructed as 'white', striving to close the fissures between Dutch-speaking and English-speaking citizens. A range of opiated narcotic medicines, designated for use by Boer families in the countryside, were exempted from the Medical, Dental and Pharmacy Act of 1928, the Union's first national pharmacy legislation. ${ }^{16}$

Political management of opioid drugs for subjects categorised against different definitions of civil and uncivil statuses was a notable development in the wider context of South Africa's modern statecraft. ${ }^{25}$ It was a moment in which official legitimation of opium uses, users and profiteers was defined in demographic terms, according to the shifting political and economic agendas of powerful actors. Self-regulation of drugs and medicines long remained a prerogative of white citizens in South Africa's racial regime, with iatrogenic addiction a generally private affair when affecting respectable families. Meanwhile, the purchase of certain narcotic patent medicines by indigenous Africans was legally prohibited..$^{17}$ In these cases, however, regulations were instituted not through medical legislation but rather as criminal controls over a prohibited substance.

Through the lens of opium, then, we see the development of South Africa's pharmacopolitics, processes that were constitutive of the modernity both of the state and of the pharmaceutical. This is not to say that such processes governed, either de facto or de jure, the medicinal consumption and health practices of South Africans, or that routes of access remained monopolised by formally sanctioned institutions. ${ }^{26-29}$ As state capacities for standardisation and surveillance grew, along with the demands of patients and the political leverage of organised pharmacy, narcotic substances and pharmaceuticals were subject to greater regulation. The next section demonstrates that, with pharmaceutical innovations-another feature of medical modernityincluding the development of new sedatives and analgesics- the stakes of medicinal access, distribution, marketing and control increased further.

\section{Thalidomide and struggles for a new regulatory regime: South African pharmacopolitics, 1920s-1960s}

The passage of the Medicines and Related Substances Control Act (101) of 1965 was another decisive legislative moment in and the outcome of South African pharmacopolitics. It provided for the establishment of a Medicines Control Council (MCC), and gave statutory authority to a medical drugs' regulatory regime that remained, with varying degrees of success, in place for the next half century. Before this Act, the Medical, Dental and Pharmacy Act (13) of 1928 had required that 'various medicines and substances' be alocated to schedules. There was, however, no effective mechanism for the registration, and therefore technical control, of medicines - including pharmaceuticals. The 1965 Act would significantly widen the legal ambit of state powers, to 'govern the manufacture, distribution, sale, and marketing of medicines. ${ }^{\mathrm{i}}$ As with the extension of drugs regulation in many other countries, gaining the support of local pharmaceutical manufacturers and professionals for such comprehensive legislation had long been frustrated, however, and was reached only in the wake of the 'thalidomide disaster' of the early 1960s (for the USA see Carpenter ${ }^{30}$ ).

Indeed, from the 1930s, successive South African administrations-whether those of the South African Party or the (Apartheid) National Party after 1948-continued attempts to expand the state's reach over the definition of what comprised a medicine, a poison and a 'harmful substance'. ${ }^{31}$ Another area of friction between pharmacy lobby groups and the Department of Public Health was the locus of pharmaceutical expertise with regards to drug safety. Chemists and druggists continued to lay proud claims to accumulated experience, and skills acquired through apprenticeship, knowledge of locally available botanicals, minerals and climates, as well as personal connections with customers. They referenced and dispensed drugs in accordance with the pharmacopoeia of Britain and of the USA. However, state-supported and commercial facilities for the testing and standardised production of medical preparations and products (eg, intravenous fluids and insulin) expanded especially from the 1940s, through such bodies as the South African Bureau of Standards.

Such entities developed as a response to the changing times and patterns of medicines consumption. Even before the global reach of the 'antibiotic revolution' after 1945, there was very rapid growth in a large and varied medical market, including in South Africa. The 1920s, and in particular the 1930s, saw an explosion in the creation and mass production of synthetic drugs, both proprietary and prescription. Undermining local manufacturing capacity and escalating the price of medicines, most of these new preparations were imported into South Africa from Europe or the USA and, by the mid-20th century, many of the best-selling products of multinational companies circulated across southern Africa.

Here, manufacturers, pharmacists and consumers were as eager as anyone else to embrace this 'therapeutic revolution. ${ }^{32}$ By the 1950s and early 1960s, pharmaceutical modernity was apparent in advertisements for synthetically created tranquillisers, enemas, antiemetics, purgatives, laxatives, antidiarrhoeal medications, slimming pills, vitamin supplements, stimulants and oral contraceptives which flooded the pages of medical and pharmacy journals. These largely-though not exclusivelytargeted patients/consumers who could afford them or who were supported by medical aid schemes and state healthcare: in other words, the white working and middle classes. ${ }^{33}$

In 1961-1962, a government commission into costs in the health sector estimated that as many as 200 new preparations (some were different brands of the same substances) were being launched in South Africa every month. In addition, more medicines were being prescribed by doctors than before. The most popular identified categories were, in this order: antibiotics, tranquillisers, 'steroids and other hormones', 'vitamines' (sic), 'anti-histamines' and medications 'for heart and blood vessels'. ${ }^{34}$

${ }^{\mathrm{i}}$ Medicines and Related Substances Control Act, 101 of 1965: To provide for the registration of medicines intended for human and animal use; for the registration of medical devices; for the establishment of a Medicines Control Council; for the control of manufacturers, wholesalers and distributors of medicines and medical devices; and for the control of persons who may compound and dispense medicines; and for matters incidental thereto. 
Such new drugs offered large profits. They held out the glossy promise of a (racialised and gendered) psychological, physiological, pharmacological modernity, characterised by appeals to scientific certainty, individual choice, personal control, and the quiescence and containment of unsettling mental or bodily conditions. This 'Golden Age' of pharmaceutical modernity was driven by, and gave rise to, changes in consciousness about the possibilities of chemicals and medicine; and also new conceptualisations of the body and mind and how they might be calmed or stimulated, controlled or invigorated. The unprecedented tide of new pharmaceuticals also gave rise to a reorganisation of chemical capital, more sophisticated technologies of production, and, as soon became clear, new dangers, which would prove the need for new forms of regulation.

As was happening elsewhere, South African pharmaceutical politics saw skirmishes and struggles within and between different factions: notably, between professionally recognised pharmacists, medical doctors, drugs manufacturers (national and international) and the state. Over these decades there were a number of attempts to put to parliament legislation that would require that the components of all human medicines (prescription, proprietary and patent) be registered. ${ }^{3536}$

Multiple issues and competing interests combined to form a logjam however, and by the early 1960 s no such legislation had been passed. The principle that pharmaceutical prescription and sales needed to be regulated was not the sticking point. Rather, agreement could not be reached over the state's powers to regulate the pharmaceutical profession, the latter's rights to trade in certain categories of goods, or about the composition and balance of representation-commercial, medical, pharmaceutical and state-on the proposed medicines regulatory bodies. As late as 1963, a lobby group including the Pharmaceutical Society of South Africa, the Pharmaceutical and Chemical Manufacturers' Association and members of the political opposition, the United Party, combined to 'filibust' debate on the South African Drugs Control Bill, then before parliament. ${ }^{37}$ The impasse ended only when the shocking extent of the thalidomide disaster in several countries became apparent. In fact, in hindsight, South African pharmacists and lawmakers alike metaphorically shook their heads when they considered just how close to its own tragedy the country had come. In 1965 Minister of Health, Dr Albert Hertzog remarked that '(we) were spared the dreadful results of this drug in England, but only by luck. Fortunately, the firms were (so) busily engaged in marketing this wonder drug in other countries...? 38

Thalidomide was a new, synthetic, chemical compound, created in 1954 by the erman company Chemie-Grünenthal $\mathrm{GmbH}$, which had first attempted to gain a share of global markets for antibiotics. Turning next to the lucrative world of sedatives and tranquillisers, thalidomide was initially sold as such. It was soon included as a component of dozens of different medicines-for coughs, sleeplessness, nausea, anxiety, asthma and gastric complaints, for example. The most well known thalidomide preparations were Contergan and Softenon, two of its German brand names; sold as Distaval by British licensee, Distillers Company Biochemicals Ltd (DCBL) after 1958.

Variations in international laws meant that in only some countries a doctor's prescription was required to purchase thalidomide-containing preparations. In others, including in West Germany, over-the-counter sales boomed. Doctors and sales representatives were given large quantities of samples, which were given out freely to pharmacists, dentists, general practitioners and others. Thalidomide was therefore sold quite legally in dozens of countries, under dozens of brand names. It was also distributed by sales representatives in order to spur the creation of new markets.

In mapping the exports of thalidomide to more than a dozen African countries during this time, historians Julie Parle and Ludger Wimmelbücker have established that African markets, initially for antibiotics and later for thalidomide, were being expanded by Grünenthal from the late 1950 s. Although Grünenthal was granted South African patent rights for several of its thalidomide products, it did not pursue active sales campaigns in South Africa. There are records of exports of only a very small amount of Softenon (a thalidomide monopreparation, a sedative) directly to a single German general merchant in Port Elizabeth in 1960-1961. And, at the same time, DCBL was opening markets in Southern Africa. It advertised Distaval in then Rhodesia as early as $1958 .^{39}$

It can be argued that African countries 'escaped' the thalidomide disaster because of the nature of post-World War II and early Cold War markets and economics, which were closely tied to race and gender. There are two lines to this reasoning. First, in settler colonies, perhaps especially South Africa, markets for sedatives (whose targeted customers were, largely-although not in absolutely every instance-white and middle class) were already well established, with plenty of similar products available. Most of the international best-selling tranquillisers-such as the American block-buster, Miltown-were sold in South Africa. Making sales headway for thalidomide preparations such as Softenon, Contergan or Distaval was therefore difficult.

Second, and significantly, across the African continent, it was sales of Grünenthal's product Entero-Sediv that were especially high: in Sudan, Ethiopia, Ghana, Guinea and Mozambique, among the poorest countries of the continent. ${ }^{40}$ Entero-Sediv was intended for the treatment of intestinal infections and diarrhoea. ${ }^{40}$ Crucially, whereas Softenon and Contergan comprised 'pure' thalidomide, Entero-Sediv contained far lower concentrations of the drug and marketing for its use was not skewed towards women in their first trimester of pregnancy. Evidence of the strength of markets for Entero-Sediv created in Africa can be understood when we note that after the withdrawal of thalidomide by Grünenthal in November 1961, a similar product was almost immediately reissued with the same brand name (but now without the thalidomide component). It was sold throughout the developing countries, including many in Africa,

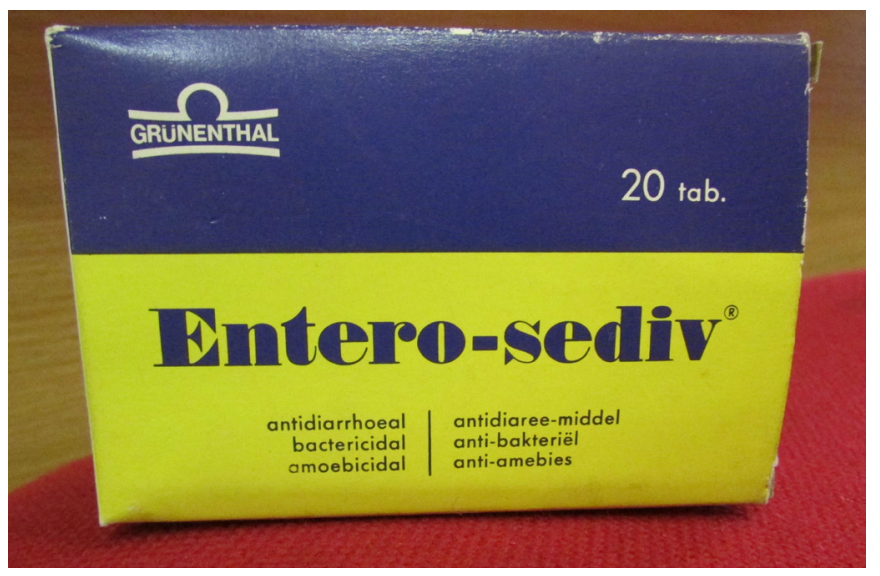

Figure 2 Package of Entero-Sediv, date unknown, but probably the 1970s. South Africa Pharmacy Museum and Library, Pharmacy House, Johannesburg, 2015. 
and extended to new markets such as South Africa. An example is shown below in figure 2 .

Thus, it was economic factors, not chance or luck, nor adept pharmaceutical governance or legislative oversight that were likely to have averted a large-scale African incidence of thalidomide-affected children being born in the early 1960s. Nonetheless, South Africa is one of the many countries where thalidomide's impact profoundly influenced pharmacopolitics, raising questions about the unhindered 'progress' of modern medical science, and blunting opposition to the expansion of state authority and medicines regulatory requirements.

The passage of the Act in 1965, and the functioning of the MCC after 1967, certainly did not mean that the South African MCC ever had the capacity to register, test or monitor all medicines and 'related substances'. Nor did it mean that agents of the Apartheid regime would refrain from using medical-and especially chemical-means of causing harm. However, at times the MCC could be a platform for progressive political voices, such as when, in the mid-1980s, its long serving chairman, Professor Peter Folb, challenged the state's use of outlawed formulations of tear gas on civilians, or in 1997-1998, when the MCC rejected the human testing of Virodene, a bogus AIDS treatment. ${ }^{41}$

Moreover, as the next section shows, the formal end of Apartheid from 1994 did not see the end of harmful medical practices and policies, and did certainly not erase decades-long popular suspicions of biomedicines and their use by the state. Seemingly intractable social determinants of (dis)advantage, especially in terms of gender, class and geography, still shape access to, and choice of, pharmaceuticals in profound ways. New drugs-both proscribed and prescribed-pose new challenges for regulators, and new dilemmas for access and inclusion. Nonetheless, what is different about this new era of South African pharmacopolitics is that it is playing out in a context in which consumers and citizens have constitutionally guaranteed rights to health. The need to define such rights in practice is one of the most pressing of South African democracy.

\section{Contraception and statecraft from 'High Apartheid' to the present: the Dalkon Shield and Implanon}

The 1960s and 1970s in South Africa are designated as the era of 'high Apartheid'. ${ }^{42}$ During this time, the Nationalist government expanded its control over state functioning, including through the provision of healthcare in accordance with the tenets of racialised rule. The consolidation of Apartheid as a system of governance, and its expression through attempts at greater demographic control over citizens, was intertwined with technological developments, including in pharmaceuticals. As described in the previous section, the growth of domestic markets for pharmaceuticals, and their attempted regulation by an increasingly assertive and, especially after the 1970s, militarised South African state, characterised these decades. Imports of contraceptives formed part of the rapid expansion and diversification of South Africa as a market for pharmaceuticals. As revealed in the case histories of opioids and anxiolytics, this had gathered momentum from the beginning of the 20th century. From mid-century in particular, coinciding with the 'Golden Age' of pharmaceutical production, it grew spectacularly.

From the 1960s, the mass production of hormonal contraception portended potential alignment between Apartheid's demographic aims-including the reduction of population growth among the black majority. ${ }^{43} 44$ It was in this decade that the state first began to provide free access to contraception through its network of public clinics. ${ }^{45}$ South Africa's National Family
Planning Programme was established in 1974, with significant state resources invested in a new pharmaceutical infrastructure to procure, promote and provide modern methods of fertility control.

Entanglements between public demand, political regulation and private profit are a further feature of modern pharmacopolitics. The successes of Apartheid's family planning programme cannot be attributed solely to the imposition of authoritarian state controls or to corporate profits. The substantial uptake of contraceptive services, and their sustained popularity across half a century, reveals the willingness of millions of women, across demographic divides, to control their fertility using modern technologies. ${ }^{46}$

Between 1974 and 1983, the number of state clinics offering contraception increased 20 times, with over 36000 contraceptive points in operation in 1983. By the early 1990s, as South Africa's democratic transition was under way, the state provided free access to contraception from over 60000 locations. ${ }^{47} 48$ Many of these were made up of mobile clinics or were private pharmacies that provided clinic services to their customers. At both clinics and pharmacies, quarterly visits were scheduled to coincide with intended return dates for the contraception injection depot-medroxyprogesterone acetate, known commonly as 'Depo'.

As the science of modern contraception advanced, new technologies were added to the menu of birth control methods available in South Africa's public health sector. In addition to hormonal injections and oral contraceptive pills, the state also promoted access to long-acting contraceptives, including intrauterine devices (IUDs). From the mid-1970s, a panoply of IUDs was available, among them the Lippes Loop, Margulis Spiral, Copper T and Dalkon Shield. ${ }^{49} 50$

The Dalkon Shield had been developed by the Dalkon Corporation, and acquired by the company AH Robins in 1970. An aggressive marketing campaign, which promoted the device as 'modern', 'superior' and 'safe' accompanied its introduction to a global market. At its peak use, over 4.5 million women in 80 countries were using the Dalkon Shield. ${ }^{51}$ Yet, by the early 1970s, evidence was mounting of its harmful and, in some cases, fatal effects on users, including increased risk of pelvic inflammatory disease, septicaemia and spontaneous abortion. In 1974, facing compensatory claims by over 200000 women in the USA, AH Robins withdrew the device from the US market. ${ }^{52} 53$ Despite mounting information about its health hazards, however, $\mathrm{AH}$ Robins continued to sell Dalkon Shields in the global market, including reportedly to South Africa for use in its national contraceptive programme. ${ }^{54}$ Ongoing marketing of the Dalkon Shield, in the wake of negative health findings, provides historical evidence of how purveyors of pharmaceuticals evaded the consumer protections regulating medicines distribution in the global north, exploiting weaker control mechanisms in the south. ${ }^{5556}$

Whereas thalidomide had not entered South Africa because of competition from similar products, for other pharmaceuticals and medical devices it was the relative porosity of the market, and the alignment between a technology's purpose and its political utility, that perpetuated public provision. As with the history of opium for Chinese mine workers, the case of the Dalkon Shield highlights tensions between the profit motive of pharmaceutical purveyors and the health interests of consumers. While the Dalkon Shield did eventually disappear from the South African market, other IUDs continued to serve as a staple of South African birth control, meeting patient demand for a long-acting, discrete, reversible contraceptive device that did not require quarterly return appointments. ${ }^{57}$ 
South Africa's transition from Apartheid to the democratic era in the 1990s transformed the national health systems, greatly expanding public access to care. However, due in part to historical associations with racialised population control, dedicated contraceptive programmes were deprioritised by the new government. As national population policies were rewritten and primary healthcare programmes expanded, the range of contraceptives available to women in the public sector was in reality reduced. While a variety of methods continued to be advertised on the walls of family planning facilities, in practice, access to long-acting, reversible contraception, in the form of IUDs, became increasingly rare.

In the late 1990s, data from the South African Demographic and Health Survey indicated that $8.5 \%$ of women currently using contraception had used an IUD, a relatively high proportion. ${ }^{58}$ Revealingly, current IUD use was most common among women in their 40s (between $8.8 \%$ and $8.1 \%$ for women aged 40-49 years), whose familiarity with the method likely related to its erstwhile promotion, as part of the state's Family Planning Programme in the 1970s and 1980s. ${ }^{59}$ By 2003, IUD use among women aged 15-29 years had become almost anomalous, with fewer than $2 \%$ of women in this age group and currently on contraception using this method. Common stock-outs of medical supplies essential for IUD insertion-including swabs, surgical lamps and scissors-hampered their provision. While reproductive freedom remained a firm commitment in state rhetoric, public provision of contraceptive options grew more limited in the first two decades of democracy.

By the third decade of the post-Apartheid period, the systemic challenges of the state's contraception programme and its practicable effects on public health were increasingly apparent. The reliance on Depo and oral contraceptive pills took on new significance as a growing research base explored associations between use of hormonal contraception and HIV-transmission risk. ${ }^{6061}$ This generated intense debate about continued provision of hormonal contraceptives, particularly injectables, as the most popular method for women in the public health sector. ${ }^{62}$ In addition, public scandals over the incidence of teenage pregnancy, illegal abortion and 'baby dumping' raised questions about the effectiveness of the state's transition from 'population control' to 'reproductive rights' ${ }^{63-67}$ The prevalence of teenage childbearing has remained relatively high in the post-Apartheid era. In the mid-1990s, the Ministry for Welfare and Population Development recorded a teenage pregnancy rate of 330/1000 for women under the age of 19 years. ${ }^{68}$ A decade later, approximately a quarter of 20-year-old South African women had given birth in their teens. ${ }^{69}$

Alarmed by such reports, the state embarked on an ambitious programme to diversify its contraceptive method mix, introducing a new, long-acting device through the public health sector (see figure 3). In 2014, the Department of Health began a national campaign to roll out the contraceptive implant, Implanon, marketed by the pharmaceutical corporation Merck. Implanon is a match-sized, flexible rod, made of silicone, containing $68 \mathrm{mg}$ of the hormone etonogestrel, which is slowly released into the bloodstream. It is described as among the most effective contraceptives ever developed, more effective even than sterilisation. ${ }^{70}$ But assumptions about its efficacy are premised on models of 'perfect-use': that, once inserted, the implant will remain in situ, in the upper arm of its user, not requiring further medical attention such as counselling to demystify its biological workings, or treatment of its potential side effects.

Thousands of nurses were trained in Implanon insertion and, within 4 months, 362000 implants had been inserted

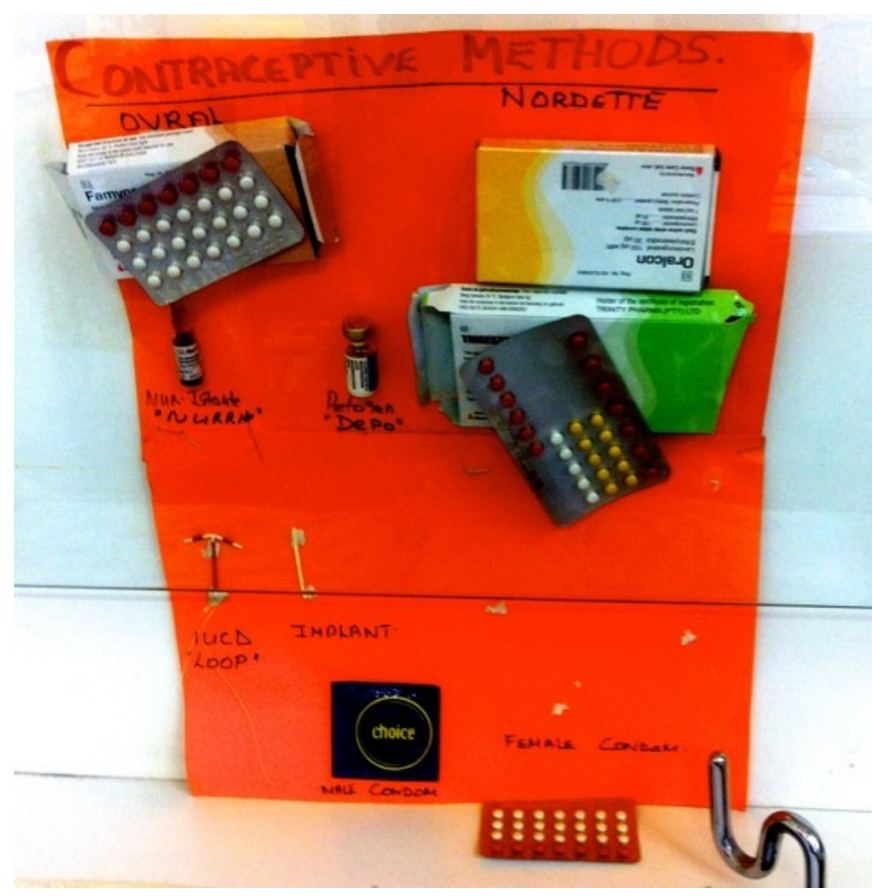

Figure 3 The contraceptive 'method mix' advertised as available in public health facilities (Eastern Cape, November 2014).

nationally, an expression of mass support for Implanon's roll-out within health facilities. ${ }^{71}$ Within the province of Eastern Cape, nurses received Implanon training in 2013, and began to insert the device into hundreds of patients per month. ${ }^{\text {ii }}$

Soon thereafter, women began requesting that their implants be removed. One patient explained, 'People were very excited at first about this. But now the excitement has changed... into panicking. ${ }^{\text {iii }}$ At one day hospital, a nurse recounted: 'They came in bulks, when they heard (about Implanon) over the media. But now, there are not that many anymore. They read the side-effects of it. They are not coming in bulks now, not as they were doing before. iv

Rumours about Implanon's toxic effects on the body, combined with their own experiences of side-effects, made the device a source of growing fear and anxiety for many women, as well as for their loved ones. By 2016, requests for Implanon removal were alleged to be so common in public health facilities around the Eastern Cape that the device was nicknamed 'Outplanon'. Healthcare workers developed strategies to stem the tide of requests for Implanon removals, including persuasive counselling, referring patients to other facilities for the removal process (in the knowledge that the burdens of transport costs and time might deter them from removing the device), mandatory requirements of a month-long waiting period after the request for removal, and outright refusals. By as early as 2014, women were removing the device themselves. Painful and potentially dangerous, this could involve puncturing the skin at the scarred site of Implanon insertion and pushing the device out of the arm.

In interviews and observations about Implanon's popular reception among patients and healthcare workers, the lasting

ii (Field notes) South Africa: Eastern Cape; 27 February 2014.

iii (Interview with a family planning nurse) South Africa: Eastern Cape; 24 October 2015.

(Field notes) South Africa: Eastern Cape; 18 August 2014. 
influence of South Africa's contraceptive histories are resonant. Among healthcare workers and patients, Implanon accrued a host of positive meanings-understood as a means of effective pregnancy prevention and reproductive autonomy for women. But its negative associations were also apparent. These drew on ideas about the physiology of modern contraception-particularly the IUD. One term for Implanon used by patients and healthcare workers in Eastern Cape-intsimbi-meaning a piece of metal or a wire-was the same as that commonly used for the IUD in the Eastern Cape in decades past, prior to its practical disappearance from the public sector. Fears of the potential side-effects caused by the implant echoed those of IUD use in the 1970s and 1980s. These included the destruction of fertility even after the device's removal, headaches, lethargy, water retention, and the threat that the device would 'wander' to other parts of the body and damage vital organs. In interviews, patients and healthcare workers recounted how older relatives in particular had warned them against using the Implanon due to its perceived similarities with the IUD.

As with the case of opium and opioid patent medicines in the early 20th century, and the various therapeutic applications for which the mid-century synthetic drug thalidomide was purportedly developed and marketed, contraceptive implants demonstrate why historicised understandings of 'the pharmaceutical' and 'the state' are essential for making sense of the ongoing complications of medicinal access and inclusion. South Africa's pharmacopolitics is situated within historical contradictions of consumer demands, marketing and distribution patterns, regulatory governance and relations of power (race, class and gender) that shaped, and were also constitutive of, healthcare management across the century.

\section{CONCLUSION}

Histories of pharmacopolitics in South Africa reveal struggles over biochemical practices and forms of consumption. Across the 20th century, techniques of rule increasingly embraced the distinctively modern project of managing the vitalities of subjects and citizens-for labour power, health and population management-through the regulation of chemical substances and technologies. The nature of the laws, policing, medical bureaucracies and professional lobbies, through which medicines and drugs came to be (partially) governed, both reflected and reproduced the ideologies and inequalities of race, class and gender of the late colonial, Apartheid and democratic periods. Over the century, elaboration of regulatory mechanisms and policies was responsive to the moral and political concerns of changing electorates. Attempts at greater pharmaceutical regulation have also sprung from a commitment to more robust protections of consumers, including through introducing more rigorous forms of pharmaceutical oversight and testing. They were shaped, too, by patient demand, the formation of informal or illicit drug economies and routes of access, and various means of non-compliance and direct resistance.

We have sought to reveal key aspects of these processes through a focus on the cases of three medicaments-opium, thalidomide and contraceptive implants. These products posed important political challenges that shaped state-making and consolidation, negotiated by the architects of medical institutions and by consumers and patients.

It was during the era of the new imperialism, at the close of the 19th century, that early elements of pharmaceutical modernity became evident in South Africa. This is seen through struggles over the definition and control of opioid commodities after the South African War, for two differentially classified and positioned consuming populationsunfree Chinese migrants imported as labouring units for mine work and white residents possessing civil status in town and country. The imbrication of these struggles with government strategies for racial segregation, and the subversive responses they (in different ways) elicited, became defining trends in South African pharmacopolitics.

Pharmacological regulations and oversight mechanisms, nascent in the struggle over opiates, grew substantially in subsequent decades, particularly after the scare of the thalidomide catastrophe. Expansion of bureaucratic and regulatory powers gathered momentum from the early 1960s. As it had elsewhere, however, the thalidomide tragedy made the case for the arrogation to the state (and not pharmaceuticals producers) of the responsibility for providing the mechanisms for the testing and registration of new drugs for quality, safety and efficacy-before they could be formally marketedirrefutable. The majority of South Africans were, however, economically poor, denied regular access to state hospitals or private health facilities which were obligated to use approved registered drugs. The South African state has never been able to meet fully its obligations in terms of providing access to safe pharmaceuticals, even when it gained the democratic mandate to do so in the 1990s.

Instead, within Apartheid's racist strategies of 'Separate Development' were incorporated the chemical and technological means to reduce black population growth through the creation of a nationwide contraceptive programme during the 1970s. Here, the modern entanglements of South African pharmacopolitics with ideologies of race and reproduction are discernible; yet the power of patients as consumers is also evident, as millions of women made use of contraceptive drugs and devices to control their fertility. With political transformation in the 1990s, the new African National Congress-run state sought to overcome legacies of apartheid rule and to respond to the moral, medical and pharmacological demands of its new electorate. Widespread mistrust of contraceptive technologies, as harmful to women's bodies and to their future fertility, has continued to influence popular understandings. This is particularly evident in relation to the new generation of contraceptive implants-similar, in the minds of many, to IUDs such as the Dalkon Shield, widely available in South Africa's national family planning programme in the 1970 s and perhaps even the 1980s.

Through the diversity of our sources, and the breadth of their chronology, we have sought to historicise modern pharmaceutical practices in South Africa, from the late colonial era to the post-Apartheid present. Understanding contemporary pharmacopolitics in Africa requires ways of thinking about 'the state' and about 'the pharmaceutical' as dynamic and intertwined. Ideologies of gender and race, patterns and legacies of oppression and resistance, deeply unequal relations of local and global economic powers, and flows of materia medica and biomedical knowledge have, since the late 19th century especially, mediated the healing and harming of millions. We have shown how research, focused on specific pharmaceutical products across a wide chronology, can offer essential insights within the developing field of medical humanities in Africa, as well as in relation to broader and ever-expanding geographies of pharmaceutical use. 
Acknowledgements We thank the editors of this special edition, especially Nolwazi Mkhwanazi, Carla Tsampiras and Victoria Hume, as well as Andy Gray, for their support and interest in our project.

Contributors This article has been equally coauthored. Its submission has been coordinated by the corresponding author.

Funding The authors have not declared a specific grant for this research from any funding agency in the public, commercial or not-for-profit sectors.

Competing interests None declared.

Patient consent Not required.

Ethics approval University of Cape Town.

Provenance and peer review Not commissioned; externally peer reviewed.

Open access This is an open access article distributed in accordance with the Creative Commons Attribution Non Commercial (CC BY-NC 4.0) license, which permits others to distribute, remix, adapt, build upon this work non-commercially, and license their derivative works on different terms, provided the original work is properly cited, appropriate credit is given, any changes made indicated, and the use is non-commercial. See: http://creativecommons.org/licenses/by-nc/4.0/.

\section{REFERENCES}

1 Viney W, Callard F, Woods A. Critical medical humanities: embracing entanglement, taking risks. Med Humanit 2015;41:2-7.

2 Dubow S. Science and society in southern Africa. Manchester: Manchester University Press, 2000

3 Ross R, Mager A, Nasson B. The Cambridge history of South Africa, Volume 2, 18851994. Cambridge: Cambridge University Press, 2011.

4 Daemmrich AA. Pharmacopolitics: drug regulation in the United States and Germany. Chapel Hill: University of North Carolina Press, 2004.

5 Cooter R, Harrison M, Sturdy S. War, medicine and modernity. Thrupp, Stroud: Sutton Publishing, 1998

6 Bashford A, Strange C. Thinking historically about public health. Med Humanit 2007:33:87-92

7 Arnold D, Imperial medicine and indigenous societies: Manchester Manchester University Press, 1998.

8 Marks S. What is colonial about colonial medicine? And what has happened to imperialism and health? Soc Hist Med 1997;10:205-19.

9 Beck A. A history of the British medical administration in East Africa: 1900 - 1950. Cambridge, Mass: Harvard University Press, 1998.

10 Ndege G. Health, state, and society in Kenya : Rochester: Rochester University Press, 2001.

11 Vaughan M. Curing their ills: colonial power and African illness. Cambridge, 1991.

12 Headrick R. Colonialism, health and illness in French Equatorial Africa, 1885-1935. Atlanta: African Studies Association Press, 1994.

13 Hunt N. A colonial lexicon of birth ritual, medicalization, and mobility in the Congo: Durham, N.C. Duke University Press, 1999.

14 Comaroff J, Comaroff J. Medicine, colonialism, and the black body, in Comaroff and Comaroff, Ethnography and the historical imagination. Oxford: Westview Publishing, 1992

15 Posel D. Modernity and measurement: further thoughts on the Apartheid State. Seminar paper, University of the Witwatersrand Institute for advanced social research, 1996:1-26.

16 Ryan M. A history of organised pharmacy in South Africa, 1885-1950: The Society for the History of Pharmacy in South Africa, Cape Town, 1986.

17 Waetjen T. The politics of narcotic medicines in early twentieth-century South Africa. Soc Hist Med 2018

18 Porter R. The greatest benefit to mankind: a medical history of humanity from antiquity to the present. London: Harper Collins Publishers, 1997:675.

19 Waetjen T. Poppies and gold: opium and law-making on the Witwatersrand, 1904-10. J Afr Hist 2016:57:391-416.

20 Debates of the Transvaal legislative assembly, 1905:1598-9.

21 Waetjen T. The rise and fall of the opium trade in the Transvaal, 1904-1910. J South Afr Stud 2017:43:733-51.

22 Debates of the Transvaal Legislative Assembly, 25 July 1906, 881-884; also, 30 July 1906, 888-905.

23 Berridge V. Drugs and social policy: the establishment of drug control in Britain 1900 30. Br J Addict 1984;79:17-29.

24 The Doctors' Day: Rand Daily Mail, 1909.

25 Marks S, Trapido S. Lord Milner and the South African State. History Workshop Journal 1979:8:50-81

26 Catherine Burns C. Louisa Mvemve: a woman's advice to the public on the cure of various diseases. Kronos 1996;23:108-34.

27 Flint K. Healing traditions: African medicine, cultural exchange and competition in South Africa, 1820-1848. Athens: Ohio University Press, 2008
28 Parle J. States of mind: searching for mental health in Natal and Zululand, 18681918. Scottsville: University of KwaZulu-Natal Press, 2007.

29 Wood F. The extraordinary Khotso: millionaire medicine man from Lusikisiki. Auckland Park: Jacana Media, 2007

30 Carpenter D. Reputation and power: organizational image and pharmaceutical regulation at the FDA. New Jersey: Princeton University Press, 2010.

31 Parle J. A drug, like a scalpel, in an unskilled hand is a dangerous weapon": South African struggles over pharmaceutical regulatory authority, 1930s-1960s: Seminar paper. WiSER: University of Witwatersrand, 2016.

32 Curth LH, ed. From physick to pharmacology: five hundred years of british drug retailing. Aldershot: Ashgate, 2006:10.

33 Parle J. Sedating, soothing, stimulating, and selling pharmaceuticals in mid-twentieth century South Africa. Conference paper. Stellenbosch: 25th Biennial Conference of the Southern African Historical Society, 2015.

34 R.P. 59/1962. Commission of inquiry into high cost of medical services and medicines. Pretoria: Government Printer, 1962:119-116.

35 UG 19-'36. Report of committee of enquiry into advertisements of proprietary medicines and medical appliances. Cape Town: Government Printer, 1936.

36 SC $10-' 37$. Select committee on the subject of the proprietary medicines and appliances bill' reported in April 1937. Cape Town : Government Printers, 1937.

37 Goyns DW. Pharmacy in the Transvaal, 1894-1994. Johannesburg: Pharmaceutical Society of South Africa, Southern Transvaal Branch, 1995:78.

38 Republic of South Africa. House of Assembly Debates, 1965:5329-30.

39 Central African Journal of Medicine, 1958:11.

40 Parle J, Wimmelbücker L. Dark remedy for a dark continent? Lost histories of thalidomide in Africa in the 1950s and 1960s: Paper delieverd at African Studies Association of the United Kingdom, 50th Anniversary conference: University of Cambridge, 2016

41 Hodes R. Chapter one: HIV in South Africa: a brief history. Broadcasting the pandemic: a history of HIV on South African television. Cape Town: HSRC, 2014:28-9.

42 Dubow S. Apartheid 1948-1994. Oxford: Oxford University Press, 2014:1.

43 Klugman B. Balancing means and ends - population policy in South Africa. Reprod Health Matters 1993;1:44-57.

44 Hodes R. The medical history of abortion in South Africa, c. 1970-2000. J South Afr Stud 2013:39:527-42.

45 Chimere-Dan O. Population policy in South Africa. Stud Fam Plann 1993;24:31-9.

46 Ferguson D. Family planning in a predominantly non-white rural South African community. S Afr Med J 1974;48:1163-4.

47 Department of Health. National contraception policy guidelines. Pretoria: Republic of South Africa, 2002:6.

48 Cooper D, Morroni C, Orner $\mathrm{P}$, et al. Ten years of democracy in South Africa: documenting transformation in reproductive health policy and status. Reprod Health Matters 2004;12:70-85.

49 Spilhaus M. The Intra-uterine device in soweto and other township. S Afr Med J 1975:31:1302-5.

50 Karstadt B. Letter: The copper-T intra-uterine device. S Afr Med J 1976;50:2153.

51 Mintz M. A Crime Against Women: A. H. Robins and the Dalkon Shield: The Multinational Monitor, 1986:7.

52 Hutchings JE, Benson PJ, Perkin GW, et al. The IUD after 20 years: a review. Fam Plann Perspect 1985;17:244-55.

53 Cates W, Ory HW, Rochat RW, et al. The Intrauterine Device and Deaths from Spontaneous Abortion. N Engl J Med Overseas Ed 1976;295:1155-9.

54 Dowie M, Ehrenreich B, Mikin S. The Charge: Gynocide - the Accused: the US Government. Mother Jones. 1970. http://www.motherjones.com/politics/1979/11/ charge-gynocide/

55 Lexchin J. Doctors and detailers: therapeutic education or pharmaceutical promotion? Int J Health Serv 1989;19:663-79.

56 Mumford SD, Kessel E. Was the Dalkon Shield a safe and effective intrauterine device? Fertil Steri 1992;57:1151.

57 Van Dongen L. Thoughts on contraception and family planning clinics. SAfr Med 1975;49:422-65

58 Department of Health. National contraception policy quidelines. Pretoria: Department of Health, 1998:10.

59 Department of Health, Medical Research Council. OrcMacro: South Africa Demographic and Health Survey Pretoria, 2003:58.

60 Bulterys M, Smith D, Chao A, et al. Hormonal contraception and incident HIV-1 infection: new insight and continuing challenges. AIDS 2007;21:97-9.

61 Morrison CS, Turner AN, Jones LB. Highly effective contraception and acquisition of HIV and other sexually transmitted infections. Best Pract Res Clin Obstet Gynaecol 2009:23:263-84

62 Ralph LJ, McCoy SI, Shiu K, et al. Hormonal contraceptive use and women's risk of HIV acquisition: a meta-analysis of observational studies. Lancet Infect Dis 2015:15:181-9.

63 Nene Z, Hofmeyr GJ, Patel M, et al. Changes to the World Health Organization guideline on hormonal contraceptive eligibility for women at high risk of HIV: South African perspective and response. S Afr Med J 2018;108:629-31. 


\section{Original research}

64 Hodes R. Popular perspectives on teenage pregnancy in South Africa. In: Mkhwanazi N, Bhana D, eds. Young families: gender, sexuality and care. Cape Town: Human Sciences Research Council Press, 2017:17-30.

65 Hodes R, Toska E, Gittings L. Babies for bling: are teenage girls having children to access grants? HIV Nursing Matters 2016;7.2:20-3.

66 Hodes R. The Culture of Illegal Abortion in South Africa. J South Afr Stud 2016;42.1:79-93.

67 Hodes R. Abortion politics in a state in transition: contesting South Africa's Choice Act. In: Stettner S, Ackerman K, Burnett K, et al. eds. Transcending Borders: Abortion in the Past and Present. New York: Springer, 2017:171-85.
68 Republic of South Africa, Ministry for Welfare and Population Development. Population policy for South Africa: a green paper for public discussion. Pretoria: Republic of South Africa, 1995.

69 Branson N, Ardington C, Liebbrandt M. Trends in teenage childbearing and schooling outcomes for children born to teens in South Africa. SALDRU Working Paper 2013;98:1-24.

70 Steyn PS, Kluge J. Contraceptives: a guide to product selection. South African Family Practice 2010:52:499-50.

71 Mullick S, Chersich M, Pillay Y, et al. Introduction of the contraceptive implant in South Africa: successes, challenges and the way forward. S Afr Med J 2017;107.10:812-4 